\title{
COMPETITIVENESS AND RESEARCH-ORIENTED TEACHING IN ROMANIAN UNIVERSITIES: THE NEO-LIBERAL TRANSFORMATION OF THE HIGHER EDUCATION SYSTEM
}

\author{
SORIN GOG 1
}

\begin{abstract}
This paper focuses on the recent neo-liberal transformation in the Romanian education system and analyzes the genealogy of a new form of academic governance that has been implemented in higher education institutions in the past decade. It examines the role quality indicators and supplementary funding have played in the gradual embedding and naturalization of neo-liberal disciplinary reforms in universities and the specific quality enhancement policies that aimed at increasing the productivity of academic workers by stimulating the competition among them. The main argument of the paper is that in order to understand the extensive academic management based on scientometrics and recurrent evaluation of academics we need to look at the structural mechanisms that have shaped higher education institutions in accordance with market rules and at the generalization of competitiveness throughout the system in the context of budget cuts and decreasing resources allocated to education.
\end{abstract}

Keywords: higher education governance, quality assurance, neo-liberalism, scientometrics, academic competitiveness

\section{Introduction: scientometrics and academic productivity}

During the second semester of the 2014/2015 academic year, the Rector of Babeș-Bolyai University2 notified all academic staff through a written disposition ${ }^{3}$ that both tenured and non-tenured employees (short term contracts up to three years) were required to update their research and artistic activity reports on the university's electronic platform. The document also reminded everyone that the national and international ranking of the university as well as the core funding allocated to each higher education institution was dependent on the research

\footnotetext{
${ }^{1}$ Sociology Department, Babeș-Bolyai University Cluj-Napoca, e-mail: sorin_gog@yahoo.com.

2 Babeș-Bolyai University (BBU) is the largest public university from Romania. It is located in ClujNapoca in Transylvania and it is known for its multi-cultural and multi-language study programs.

${ }^{3}$ http://www.ubbcluj.ro/ro/despre/info/infoUBB/files/InfoUBB_2015_02/Dispozitie\%20de\%20 serviciu\%20privind\%20incarcarea\%20activitatii\%20de\%20cercetare\%20pe\%20platforma\%20Managementul\%20Cercetarii_CA_04.02.2015.pdf [last accessed: 03.05.2015].
} 
activities of its staff. The written disposition concluded with an administrative admonition: "If you do not fulfil this obligation until the deadline as it was communicated to you, one of the disciplinary procedures contained in Law 1/2001 will be set in motion against you" (Hot. CA 2054/04.02.2015). In the recent history of Babeș-Bolyai University, this was a cautionary language of unprecedented strength issued by the Administrative Council4, aimed at mobilizing all academic staff to report their research in the institutional established evaluation forms.

Shortly after this, the Rector issued a new written disposition 5 , this time to take issue with those that did not report the required amount of publications. Currently this is set at three publications for a three year period (Hot. SEN 405/03.12.2012 and Hot. CA 2882/17.02.2014), but this has never been seriously enforced in the University until now. The new notification carefully listed all the articles and paragraphs from the National Education Law that referred to teaching but also to research norms for academic staff, to the University Charter, Senate decisions and pointed out to the legal duties of employees to fulfil their contractual obligations. It invoked a strong legal grounding and it made no shortage of showing that it has all the required legitimacy to act the way it did. Then it firmly asked all deans and heads of departments to acknowledge that, according to a decision taken the previous academic year6, it was their duty and obligation to implement the necessary measures in order for faculty members to fulfil the specified minimum research requirements. Referring to his legal attribute as manager of the University, the rector demanded the following steps to be taken: the deans (together with the heads of departments) of the 22 faculties were asked to nominate a local disciplinary committee that the Rector's Office would forward to the University Senate for approval; all deans had to submit three separate lists to the Rector's Office: one with all academics that did not report any publications for 2014, a second with all the academics that had an average number of less the three publications for the 2012-2014 period, and a third list with academics that did not report any publications during the last three years. The written notification concluded once again with a strong, almost military language, stating that the infringement and non-compliance with these directives constitute a "violation of hierarchical orders" (Hot. CA 2627/ 11.02.2015).

\footnotetext{
4 The Administrative Council is the executive branch of the University and it is composed of the rector, vice-rectors, and faculty deans of BBU.

${ }^{5}$ http://www.ubbcluj.ro/ro/despre/info/infoUBB/files/InfoUBB_2015_02/Decizie\%20privind\% 20incarcarea\%20activitatii\%20de\%20cercetare\%20pe\%20platforma\%20Managementul\%20 Cercetarii_11.02.2015.pdf [last accessed: 03.05.2015].

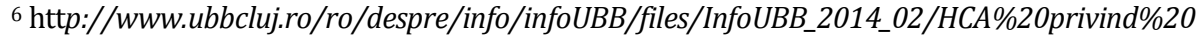
publicatiile\%20aferente\%20componentei\%20de\%20cercetare\%20din\%20norma\%20universitara\% 20nr\%202882\%20din\%2017-02-2014.pdf. Retrieved from: http://www.ubbcluj.ro/ro/despre/info/infoUBB/ [last accessed: 03.05.2015].
} 
COMPETITIVENESS AND RESEARCH-ORIENTED TEACHING IN ROMANIAN UNIVERSITIES: THE NEO-LIBERAL TRANSFORMATION OF THE HIGHER EDUCATION SYSTEM

The disciplinary process is still pending, but the initial idea was that the local disciplinary committees would evaluate each single case and would implement specific sanctions against academic staff together with the Senate and the Administrative Council - these punitive measures would range from written admonitions to the actual increase of teaching load. These disciplinary procedures and this instantiation of hierarchical control mechanisms related to academic productivity are also unprecedented in the recent history of the University. The number of research publications required from each staff member is not much given the existing formal requirements and types of publication accepted to be taken into consideration by the University. Nevertheless we should take a step back and notice how the internal quality assessment process that was started a few years ago was now completing a full cycle and was gradually transformed into what it actually was meant to be: an apparatus for standardizing, measuring and comparing academic performance that is instrumental for a neo-liberal reform of higher education that relies on a full implementation of scientometrics in order to articulate a new form of management based on competitiveness and the relocation of resources to those academic institutions that are more willing to implement market-oriented reforms. Part of these transformations is the constitution of an extensive disciplinary mechanism that individuates and makes each single academic a responsible and accountable member of the "sustainable" and "productive" academic environment. The implementation of these neo-liberal technologies of knowledge production in the higher education institutions at the periphery of European Union and the way the integration of these countries into the Single European Market has impacted the existing education systems are still pending a thorough ethnography.

Gradually, at Babeș-Bolyai University, as well as throughout the Romanian academia, a digitalized system has been set up to meticulously quantify the most detailed movements in the academic space. Initially, the online system appeared as a handy and modern(izing) tool to organize one's research activity while allowing access to it from everywhere. It soon turned into a device that required every member to report and categorize their academic activity. The online system distinguished between types of publications and it carefully differentiated between the ranks of these publications: for example, the papers published in scientific journals were differentiated according to their level of prestige - ISI publications (abbreviation for Institute for Scientific Information owned by the Thomson Reuters Corporation), IDB publications (International databases other than ISI), CNCSIS publications (national databases) and other Romanian publications. Published books were also ranked according to four hierarchical categories which distinguished for example between "recognized" international publishing houses such as Cambridge University Press, Blackwell or Sage and 
other international publishing houses. The production of local knowledge in vernacular languages and the dissemination of research to national stakeholders was gradually devaluated by the institutionalized requirement to publish in international trade languages and international publishing houses. The data collection also codified conference proceedings (using a similar ranking system as journal publications), edited volumes, translations, grants and other institutional projects. Furthermore, it asked for grant applications you submitted to be mentioned, even those that did not receive financing or are still pending review, so that it could measure how industrious employees are. The 'scientific prestige' of academics was measured in a comprehensive and meticulous manner: membership in research centres, professional associations, editorial boards, conference committees, doctoral committees, awards received, guest lectures at international or national universities, project expertise, appearances in the public sphere etc.

Because of the low integration of local evaluation systems with the national ones, university employees are periodically asked to fill in additional evaluation reports that require other complex performance indicators such as number and types of citations of personal publications, calculate the impact of these citations through the Hirsch index, quantify the new directions of study programs in university that each individual academic has initiated, the creation of new courses for students, number of BA and MA supervised thesis, the contribution to studies that ground or evaluate public policies etc. These evaluative systems grow more complex each year and have become an important managing tool for all public administrators that deal with higher education governance. What it is important to point out is not only the wide diversification and quantification of these evaluative indicators but the construction of devices that enable a macro-micro scaling of performance: the insertion of all higher education institutions into a common classifying grid which enables the identification of those national universities that perform under the global average or the specific research dimensions that are malfunctional and, at the same time, single out those exact academics from the specific departments belonging to one of the faculties that has not been productive enough. The above mentioned written notifications that were sent out by the Rector and the disciplinary procedures set in motion against those that had not fulfilled the research quota need to be understood as a function of the successful concatenation of the intersecting macro-micro devices which have been introduced in the Romanian academic institution as standard(izing) managing tools.

Not only has the research done by universities been dealt with through the institutionalization of scientometrics, but teaching activities have also undergone the same transformations. A common feature of each semester is the possibility of an electronic evaluation by students of each course or seminar taught by academics 
which enable heads of departments and deans to identify how students perceive the performance of each employee. Initially, the student's evaluation was designed as an instrument for feed-back that professors could consult to improve their curricula, readings, level of intelligibility and class performance. Attempts have been made to incorporate these evaluations into how employees are financially remunerated within each department, but due to the general freezing of wages this attempt has been temporarily blocked. Nevertheless, the new Educational Law adopted by Parliament explicitly specifies that the evaluation of courses by students is mandatory and that this has to be incorporated in deciding how professors are remunerated, along with other performance criteria. (Law of National Education 1/2011, Art. 303: 1,2,3).

In addition, the feed-back functions of evaluation have been dealt with in a more direct and controlling manner. As of 2014/2105 academic year, BabeșBolyai University implemented a national requirement issued by ARACIS7 which asked each single department to organize 'inter-collegial' evaluation sessions. This meant that each academic year, $25 \%$ of the department's staff had to be evaluated by peers and that this would be a permanent activity that would be rerun every four years. The evaluation committee was set up by colleagues from the department, approved by the head of the department and dean and would have to reflect the existing (power) structure: junior-lecturers and lecturers could be evaluated by all academics, assistant-professors and fullprofessors only by colleagues of a similar rank. The evaluation focused on three aspects: teaching, research and administration. The evaluated academic had to receive a grade for distinct dimensions of each of the three aspects ${ }^{8}$. All this data is centralized by a specialized institution belonging to the University: the Centre for Academic Development and Quality Management.

It is important to notice how extensive the evaluation of University's employees is becoming and the fine tuning it operates in order to take each single dimension of academic activity into consideration, not only in terms of

\footnotetext{
7 The Romanian Agency for Quality Assurance in Higher Education (ARACIS), www.aracis.ro.

${ }^{8}$ For example, "teaching" meant the evaluation by peers of the specific portfolio of each course and the way it was organized, the scientific content of the course, the resources for learning that the professor made available to students, the way the evaluated professor interacted with students, the communication skills and the system of grading students that was employed. The "research" aspects were operationalized in three dimensions: national and international publications, the active involvement in research grants and professional prestige (measured in terms of belonging to different professional association or participation at scientific events). The "administrative" aspects were also well covered by the evaluation procedure: how each member fulfilled their official institutional duties, the involvement in the particular administrative tasks existing in the department (the partaking in the creation of reports required by the university was emphasized as well) and, finally, the involvement in organizing scientific events or services for the community.
} 
research, but in terms of teaching and administrative work as well. It operates through a genuine surveillance mechanism that mobilizes co-workers to analyze, evaluate and measure the professional activity of each individual member of the department. In what follows I would like to explore the structural mechanisms behind this process of extensive evaluation and the reasons why it has escalated in recent years. My main argument is that this is related to a radical neo-liberal reform of higher education in Romania and to the implementation of a new form of academic governance in which all employees are disciplined, put under surveillance and penalized in order to become responsible and hardworking members of a market-oriented enterprise that is capable of supplying competitive educational services.

\section{Funding of the Higher Education System and internal quality assurance mechanisms}

In order to understand these transformations we have to take a look at the way higher education institutions have been financed in Romania and the new mechanisms of budget allocations that have been set in motion in the past seven years. I would like to focus on the notion of "supplementary funding" (finantare suplimentară) or funding based on academic "excellence", that received a growing attention in the documents produced by the National Higher Education Funding Council (CNFIS) who acts, according to the Law of National Education as the institution that provides official assessments and expertise to the Ministry of Education when it comes to the distribution of financial resources among universities. One of the main reasons why the radical neo-liberal reforms have been so easily naturalized by governance bodies, professors and trade unions alike is the fetishization of supplementary funding and the idea that institutions that produce more and better scientific research are worthy of an additional allocation of resources to reward their academic prowess. This idea has become so strongly embedded in the every-day life of academic institutions that it was relatively unnoticed that this actually never happened and that behind this language of meritocracy a complex device of academic productivity enhancement was hidden that aimed at rationalizing costs, disciplining labour and instilling competition among academics - reforms which have the potential to produce a more precarious working environment. I will try to show how there is no such thing as supplementary funding in the sense of extra-funding for excellence that is allocated on top of the core-funding, only a zero-sum game that actually redistributes resources among higher-education institutions based on the brutal market logic of survival of the fittest and annihilation of the weakest. 
The institution responsible for quality assurance in Romania has been from the early 90's the National Council for Academic Evaluation and Accreditation (CNEEA), in charge of the accreditation of universities and new study programs. In the context of a massive numeric explosion of private universities but also of new lines of study provided by state universities, the Council was responsible for evaluating the institutional capacity of higher institutions, for offering qualitative educational services and for the legal accreditation of degrees. In 2005 this body was replaced by the Romanian Agency for Quality Assurance (ARACIS) that was mandated by Parliament to be in charge of all external evaluation of national universities. ARACIS is a full member of European Association for Quality Assurance in Higher Education, a network of European institutions which is responsible for implementing the European standards in higher education in all countries that underwent the Bologna Process. This means that national policies of quality assurance are continuously synchronized with European ones. Given the growing complexity of the evaluation of higher education operated by ARACIS and the fact that this process became mandatory for all universities and is recurrently applied to all study programs, the institution would play an important role in the implementation of quality standards and evaluation of the national education enterprises.

From the perspective of those managing the education system and educational policy makers, bodies such as CNEEA and ARACIS can be responsible for the external evaluation and accreditation of higher education institutions, while having only a limited impact on the internal quality assurance mechanisms. From this point of view, once a university or study program would receive the required accreditation it would not have a lasting incentive to further its quality development and enhance the educational services it offers (Stavaru, 2012: 112-113). These evaluations were done recurrently and this means that all universities are more or less compelled to implement quality assurance procedures - but what the governors of education find problematic is the fact that this might induce a threshold-mentality and could lead to the rationalization of efforts and limitation to fulfilling solely the externally imposed standards. This is why an internal mechanism of assurances was implemented as well, and, in order for higher education institutions to have genuine motives to internalize these reforms, parts of the core funding were conditioned by their incorporation. This is what bodies such as National Higher Education Funding Council (CNFIS) are responsible for - to evaluate and monitor the implementation of internal quality standards in higher education institutions and propose the allocation of funding in accordance with the public policies pertaining to quality assurance of educational services. 
Let us take a look at how these quality indicators have changed in the past decade under the supervision of CNFIS and the impact they had on the funding of higher education institutions. A major turning point in the distribution of funds took place in 1999 when the funding was allocated based on block-grants, cost-differentiation mechanisms and material costs associated with different types of study programs (Curaj et al., 2015: 6). The block-grants given to universities generated a de-centralization process in managing costs related to higher education and enabled them to have a larger autonomy in terms of how these funds were internally allocated (Analiza, 2008: 2). This new mode of governance was operational between 1999 and 2001 (for 3 years) and it introduced a few important concepts that were instrumental in distributing the financial resources among universities up to the present time. In order to standardize managerial accounting and enable a resource allocation based on the different types of costs involved in the educational process, two types of coefficients were set up. The equivalence coefficient (coeficient de echivalare) expressed the fact that the level of education (bachelor, masters, doctoral) and the language of education (Hungarian, German, English and other international trade languages) required different type of efforts and corresponding resources. The cost coefficient (coeficient de cost) expressed the different material costs involved in each domain of studies: a Film student, for example, would require more resources in order to be educated (coefficient $=9$ in 2002) then, let's say, a student in Sociology (coefficient $=1$ in 2002). Both these coefficients enable the computing of two standardizing units that were employed in order to allocate the financial resource to universities based on the weight of these two types of factors and the number of corresponding students it managed to attract: allocation per equivalent student (alocație per student echivalent) and allocation per unit equivalent student (alocație per student echivalent unitar). We will come back to these indicators in the last section of this paper. The chart below shows the evolution of the numbers of students in public universities who received statefinanced education (public universities are also allowed to act as private enterprises and offer educational services to students who can afford to cover their own costs - the exact number of self-paying student places is regulated each year by ARACIS). We can see that the number of budgeted slots allocated by the state to public universities had only a slight variation (from 2007 to 2013 it increased with 3640 places), but that the number of equivalent and unit equivalent students registered big fluctuations. This is mainly caused by the overall numeric increase of MA and PhD students and by the overall nature of the fields, levels and language of study for which money is allocated. 
COMPETITIVENESS AND RESEARCH-ORIENTED TEACHING IN ROMANIAN UNIVERSITIES: THE NEO-LIBERAL TRANSFORMATION OF THE HIGHER EDUCATION SYSTEM

Figure 1. The evolution of the number of students receiving free tuition in public universities ("budgeted")

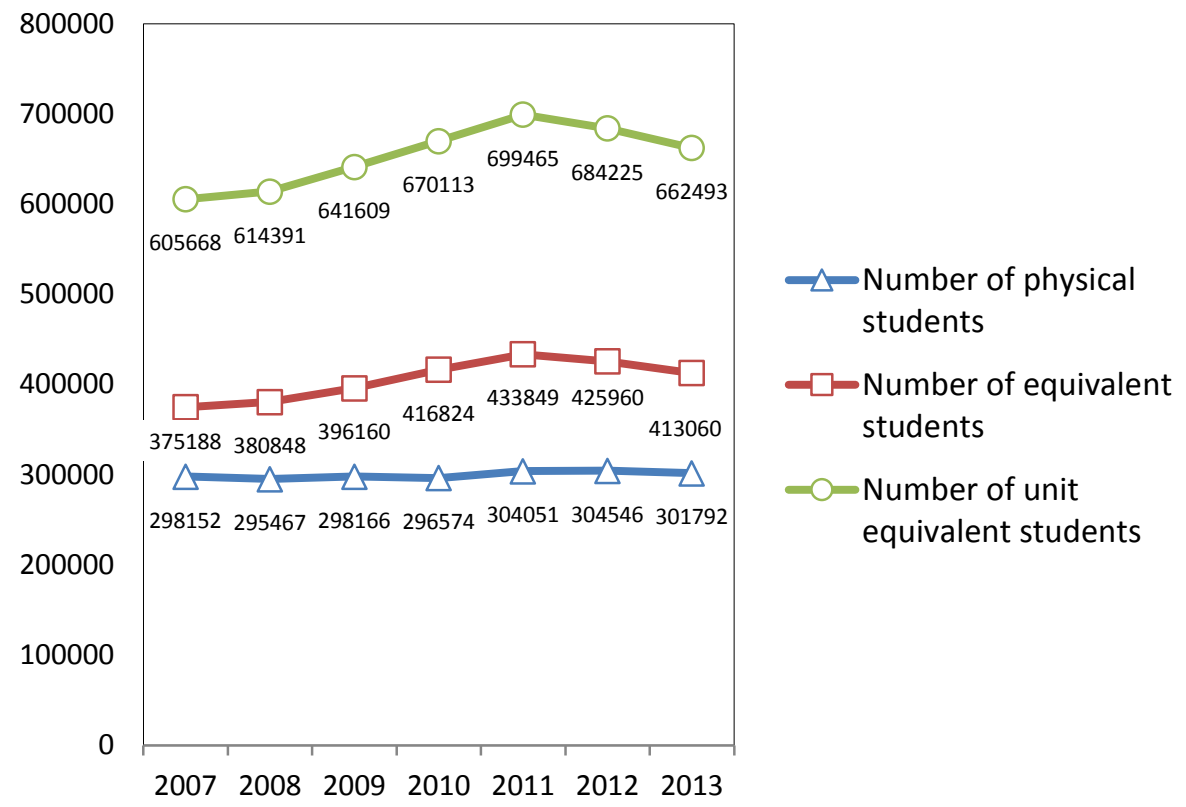

Source: CNFSIS - Raport public anual [Yearly public report] 2013.

Both the number of equivalent and unit equivalent students are dependent on the above mentioned coefficients that are established (politically) for each academic year by the Ministry of Education, which can thus adjust and control the resources allocated to higher education. Nevertheless, both the equivalence coefficient and the cost coefficient remained relatively stable in the past ten years. Table 1 shows the evolution of the cost coefficient in the past decade: except mathematics, psychology, medicine and film, all other fields of study were constant in their cost estimations.

Between 1999 and 2001, the allocation of funds to the different higher education institutions was dependent solely on a quantitative factor: the number of students universities managed to attract (determined indirectly also by the accreditation it received from ARACIS who establishes the maximum number of students a university can admit). The distribution of funds was in no way directly dependent on qualitative factors related to internal performance of higher education institutions. One of the main reasons for the introduction of these qualitative factors was to incentivize universities to implement internal quality assurance mechanisms and force them to direct their efforts not only to teaching but to research as well since this was perceived as the best way to improve the performance of academic staff and the curricula of study programs (CNFIS Analiza, 
2008: 3-4). In 2002, four quality indicators were introduced for this purpose: QI.1 (Quality Indicator) the degree of academic positions occupancy in order to stimulate universities to hire more staff and thus improve the quality of education - up to that time universities having similar number of equivalent students would receive the same type of funding even if one would have significant less number of academic personnel employed (CNFIS Propuneri, 2002: 5-6); QI.2 the quota of full professors and associate-professors; QI.3 the quota of academic staff under 35 years; and QI.4 the number of academic staff holding a doctoral degree.

Table 1.

The evolution of the cost coefficient between 2002 and 2010

\begin{tabular}{|c|c|c|c|c|c|c|c|c|c|c|c|}
\hline & 2002 & 2003 & 2004 & 2005 & 2006 & 2007 & 2008 & 2009 & 2010 & 2011 & 2012 \\
\hline Technical & 1.65 & 1.90 & & & 1.75 & & & & & & \\
\hline $\begin{array}{l}\text { Technical, without } \\
\text { engineering phys- } \\
\text { ics and chemical } \\
\text { engineering }\end{array}$ & & 1.65 & 1.65 & 1.65 & & 1.75 & 1.75 & 1.75 & 1.75 & 1.75 & 1.75 \\
\hline $\begin{array}{l}\text { Technical: engi- } \\
\text { neering physics } \\
\text { and chemical } \\
\text { engineering }\end{array}$ & & & & & & 1.90 & 1.90 & 1.90 & 1.90 & 1.90 & 1.90 \\
\hline Architecture & 2.00 & 2.00 & 2.00 & 2.00 & 2.50 & 2.50 & 2.50 & 2.50 & 2.50 & 2.50 & 2.50 \\
\hline Agronomy & 1.69 & 1.69 & 1.69 & 1.69 & 1.75 & 1.75 & 1.75 & 1.75 & 1.75 & 1.75 & 1.75 \\
\hline Sciences & 1.65 & 1.90 & & & 1.65 & & & & & & \\
\hline $\begin{array}{l}\text { Sciences, without } \\
\text { physics and } \\
\text { chemistry }\end{array}$ & & 1.65 & 1.65 & 1.65 & & 1.65 & 1.65 & 1.65 & 1.65 & 1.65 & 1.65 \\
\hline $\begin{array}{l}\text { Sciences: physics } \\
\text { and chemistry }\end{array}$ & & & & & & 1.90 & 1.90 & 1.90 & 1.90 & 1.90 & 1.90 \\
\hline $\begin{array}{l}\text { Physics and } \\
\text { Chemistry }\end{array}$ & & 1.90 & 1.90 & 1.90 & & & & & & & \\
\hline $\begin{array}{l}\text { Mathematics } \\
\text { and Special } \\
\text { mathematics }\end{array}$ & 1.28 & 1.28 & 1.28 & 1.28 & 1.65 & 1.65 & 1.65 & 1.65 & 1.65 & 1.65 & 1.65 \\
\hline $\begin{array}{l}\text { Social sciences } \\
\text { and Humanities }\end{array}$ & 1.00 & 1.00 & 1.00 & 1.00 & 1.00 & 1.00 & 1.00 & 1.00 & 1.00 & 1.00 & 1.00 \\
\hline Psychology & 1.28 & 1.28 & 1.28 & 1.28 & 1.00 & 1.00 & 1.00 & 1.00 & 1.00 & 1.00 & 1.00 \\
\hline Medicine & 1.90 & 1.90 & 1.90 & 1.90 & 2.00 & 2.25 & 2.25 & 2.25 & 2.25 & 2.25 & 2.25 \\
\hline Economics & 1.00 & 1.00 & 1.00 & 1.00 & 1.00 & 1.00 & 1.00 & 1.00 & 1.00 & 1.00 & 1.00 \\
\hline Theatre & 5.37 & 5.37 & 5.37 & 5.37 & 5.37 & 5.37 & 5.37 & 5.37 & 5.37 & 5.37 & 5.37 \\
\hline Film & 9.00 & 9.00 & 9.00 & 9.00 & 7.50 & 7.50 & 7.50 & 7.50 & 7.50 & 7.50 & 7.50 \\
\hline $\begin{array}{l}\text { Musical } \\
\text { performance }\end{array}$ & & 5.37 & 5.37 & 5.37 & 5.37 & 5.37 & 5.37 & 5.37 & 5.37 & 5.37 & 5.37 \\
\hline Music & 3.00 & 3.00 & 3.00 & 3.00 & 3.00 & 3.00 & 3.00 & 3.00 & 3.00 & 3.00 & 3.00 \\
\hline Arts & & 3.00 & 3.00 & 3.00 & 3.00 & 3.00 & 3.00 & 3.00 & 3.00 & 3.00 & 3.00 \\
\hline Sport & 1.86 & 1.86 & 1.86 & 1.86 & 1.86 & 1.86 & 1.86 & 1.86 & 1.86 & 1.86 & 1.86 \\
\hline
\end{tabular}

Source: CNFSIS - Raport public anual [Yearly public report] 2012. 
In 2003 these quality indicators were diversified to a number of 13 and they additionally included: QI.5 - the quota of post-graduate students; QI.6 - the percentage of core funding allocated to libraries and laboratories; QI.7 - the quality of academic and administrative management; QI.8 scientific research performed by academic staff; QI.9 - spending on material resources required for teaching activities; QI.10 - the quality of social and administrative services offered to students; QI.11 - quota of incomes generated autonomously by the university; QI.12 - quota of research grants and contracts; and QI.13 -quota of funds allocated to institutional development from own incomes (CNFIS Propuneri, 2003: 5-13). All these indicators were grouped in three categories: QI.1-QI.6 indicators related to the quality of didactic process having a weight of $50 \%$ in the total of quality indicators; QI.7-QI.10 - indicators related directly to the quality of teaching having a weight of 30\%; and QI.11-QI.13 - indicators related to institutional performance with a weight of $20 \%$. The implementation of these quality evaluations was accompanied by the differentiation of the funding allocated to higher education into two sections: core funding and funding based on quality indicators. For 2003 the latter would represent $12.7 \%$ of the total funding while 82.3\% would be allocated based on quantitative criteria (number of equivalent students). A special attention was given to I.Q. 8, the scientific research performed by academic staff, which would represent $3 \%$ of the total funding. Through this manner, for the first time, the funding of higher education institutions was distributed not only based on quantitative criteria (number and type of students) but based on qualitative ones as well. $12.7 \%$ of total funding represents an important amount of money and this meant that universities were under external pressure to improve their performance and implement internal quality assurances mechanisms in order to attract more resources.

In the coming decade these quality indicators would undergo a process of diversification and standardization. Their internal weight would be adjusted and readjusted in order to generate a mechanism of funding distribution that had the potential to enable universities to invest in their institutional development and allocate internal resources towards improving their performance in accordance with the different quality dimensions. In order to make this possible, a predictable environment was needed, in which the governance of higher education would be transparent enough such as to produce long-term investments in human resources and academic services. This was not always the case. In the winter of 2004, a shift in power took place and the socialist government was replaced by a liberal one. In the spring of 2006, the methodology for distributing funds to higher education 
institutions ${ }^{9}$ would change once more and the funding based on quality indicators would be raised from $12.7 \%$ to $20 \%$. This triggered an increase in the focus towards quality indicators and making universities responsible for their revenues and financial well-being. The implementation of internal reforms started becoming serious business: $1 / 5$ of the total public funding would depend on how fast these quality adjustments were implemented, since higher scores achieved by other (competing) universities meant losing money in favour of them. In 200710, the funding based on qualitative indicators was raised to $25 \%$ of the total funding and, for the first time since 2003, the QI.8 (now renamed QI.6), the scientific research done by academic staff would have a more significant role and would represent $5 \%$ of total funding. In $2008^{11}$, a new threshold would be reached: Q.I. based finance would be expanded to $30 \%$ and IQ.6 (scientific research) to $7 \%$ of the total funding. This mechanism of distribution of funds would remain the same for $200912,2010^{13}$ and $2011^{14}$. The following chart represents the evolution of the funding based on quality indicators and the percentage of total funding based on the research performed by academic staff.

For a long period of time, the students who were self-financing their studies were an important source of revenue for universities. In the context of low financing allocated by the state for higher education grants, both private and public universities seized on the opportunity to attract an increasing share of high-school students that wanted to have an BA, MA or PhD degree, but could not occupy (through competition) the state-financed positions. Because of a series of factors (demographic decline, higher standards for high school graduation), universities eventually started losing the financial resources coming from feepaying students: from 2007, the percentage of self-financing students dropped from $54.89 \%$ to $39.58 \%$ in 2013 . This meant that resources allocated on qualitative indicators would have a higher and higher stake for the university's budget and that the improvement of its global institutional performance, the activity of member faculties, the marketization of its study programs, the scientific research of its staff, etc. would play a critical role for the financial stability of the institution.

\footnotetext{
${ }^{9} \mathrm{http://vechi.cnfis.ro/fb2006/fb2006.html} \mathrm{[last} \mathrm{accessed:} \mathrm{03.05.2015].}$

$10 \mathrm{http://vechi.cnfis.ro/fb2007/fb2007.html} \mathrm{[last} \mathrm{accessed:} \mathrm{03.05.2015].}$

11 http://vechi.cnfis.ro/fb2008/fb2008.html [last accessed: 03.05.2015].

$12 \mathrm{http}: / /$ vechi.cnfis.ro/fb2009/fb2009.html [last accessed: 03.05.2015].

$13 \mathrm{http}: / /$ vechi.cnfis.ro/fb2010/fb2010.html [last accessed: 03.05.2015]

14 http://vechi.cnfis.ro/fb2011/fb2011.html [last accessed: 03.05.2015]
} 
Figure 2. Evolution of funding based on quality indicators and of the percentage from total funding based on academic research

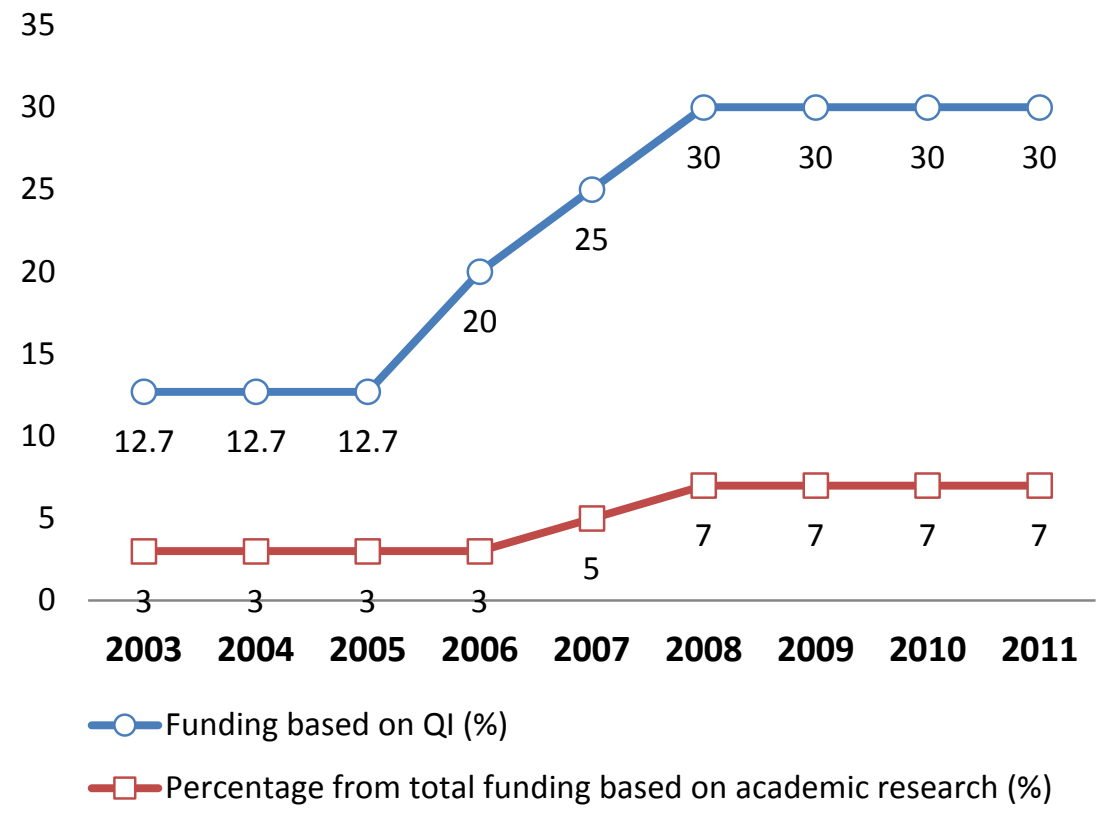

Source: Own computation based on annual methodology proposed by CNFSIS, corroborated with Radu Mircea Damian's presentation, the former president of CNFSIS http://www.mf.gov.md/common/news/112408-prezentare.ppt [last accessed: 03.05.2015].

Table 2.

Budgeted and self-financed students in public universities

\begin{tabular}{|l|rrrrrrr|}
\hline & $\mathbf{2 0 0 7}$ & $\mathbf{2 0 0 8}$ & $\mathbf{2 0 0 9}$ & $\mathbf{2 0 1 0}$ & $\mathbf{2 0 1 1}$ & $\mathbf{2 0 1 2}$ & $\mathbf{2 0 1 3}$ \\
\hline $\begin{array}{l}\text { Percentage of self- } \\
\text { financing students }\end{array}$ & 54.89 & 55.54 & 54.44 & 54.22 & 49.92 & 44.5 & 39.58 \\
\hline $\begin{array}{l}\text { Percentage of budgeted } \\
\text { students }\end{array}$ & 45.11 & 44.46 & 45.56 & 45.78 & 50.08 & 55.5 & 60.42 \\
\hline
\end{tabular}

Source: CNFSIS - Raport public annual [Yearly public report] 2013. 
A further dramatic change in higher education governance occurred in 2012, when a completely new mechanism of funding higher education institutions was implemented. This involved both a process of classification and hierarchization of universities and the distribution of resources based on the ranking of each single program of study. The percentage of quality indicators funds would remain the same (30\%) but the weight of scientific research performed by academic staff would play a tremendous role. If in $20033 \%$ of the total funding allocated based on scientific research represented $23.62 \%$ of the total funding based on qualitative indicators, in 2012 the classification and hierarchization of study programs and universities would rely on an algorithm in which scientific research would weigh between $40 \%$ (for fields such as theology, history, philosophy, etc.) and 60\% (for fields such as computer science, physics, engineering, etc.) ${ }^{15 !}$ Given that in 2012 supplementary funding represented 30\% (25\% supplementary funding based on excellence) of total funding, a mechanism of ranking higher education institutions that took into account up to $60 \%$ the scientific research done by its employees meant that the budget of a university suddenly became greatly dependant on the research productivity of its academics. Between 2006 and 2012 the funding based on quality indicators increased dramatically and so did the weight in the total funding of research done by academics. In less than 10 years the governance of the Romanian academic space underwent striking changes: in 2002 the four quality indicators did not even mention scientific research; a decade later this would be the main factor used to differentiate between fund quantities received by universities.

\section{Neo-liberal reforms in the Romanian higher education system}

Something unusual and noteworthy must have happened within the system in order for it to register scientific research of academics as one of the most important variables for allocating funds to higher education institutions. Such a disruption of existing institutionalized financial mechanisms and the embedding of a new logic of funding in which the productivity of workers is iterated as one of the main factors for differentiating among beneficiaries of public resources in order to carry out a public service, cannot be left unexplored. In what follows I would like to reconstruct the genealogy of this transformation, analyze the narratives that were mobilized for reforming higher education and show how internal quality enhancement policies (a legitimate objective for all stakeholders) have been codified as a neo-liberal instrument meant to discipline workers and make them compete against each other for the ever-decreasing resources allocated to education. The supplementary funding for excellence

\footnotetext{
15 See CNFIS Metodologie 2012 and OMECTS 5212/26.08.2011.
} 
was never what it claimed to be - it was only the objectivation of a deepseated view of a certain segment of the post-communist liberal intelligentsia that believed that the dysfunctions of the educational system could be dealt through a shock therapy and a 'civilizing' ideology that identified the predominance of 'lazy', 'mediocre' and 'parochial' academic workers as the main reason for the provincial backwardness of Romanian education.

The Presidential Commission for the Analysis and Elaboration of Education and Research Policies (PCAEERP) was set up in 2006 by then Romanian President Traian Basescu - who emerged as the leader of a right-wing liberal-democrat coalition during the early 2000's. The Presidential committee was chaired by Mircea Miclea, a Psychology Professor from Babeș-Bolyai University, who for a short period of time, (December 2004 - November 2005) was the Minister of Education in the liberal government led by Calin Popescu Tariceanu (the president of the National Liberal Party). The Committee had two vice-presidents: Daniel David (also from Babeș-Bolyai University), a psychologist and a long collaborator of Mircea Miclea, who by that time established a name for himself as an international recognized researcher and Daniel Funeriu, a chemist who held important research positions in Germany, Japan and U.S. Later on, Daniel Funeriu would become the Minister of Education and would play an important role in implementing the recommendation drafted by the Presidential Commission in the Romanian educational system.

The Presidential Report entitled A Romania of Teaching, a Romania of Research (Raportul Comisiei Prezidentiale - RCP, 2007) was one of the most evidently neo-liberal manifestos ever drafted in the national academia and it advocated new educational polices and comprehensive structural reforms. One of the acknowledged sources of inspirations of the Report was the U.S. educational system: the authors referred to the Tough Choices or Though Time Report that advocated, under the Bush jr. presidency ${ }^{16}$, strong neo-liberal reforms centred on employability, flexible workforce, long-life learning etc. The idea of the backwardness of the Romanian education system in comparison with the Western system informed the entire analysis and the selected examples focused usually on the most extreme market-oriented education policies existing in the Western countries, in order to emphasize the tremendous gap and the radical and drastic reforms needed to "Europeanize" national academia. The Presidential Report was the first document that coherently articulated an extensive and thorough reconstruction of the education system in the Romanian academic space and its adjustment to global markets and academic competitiveness. Because both the actors and the policies drafted by them in this document played an important role in the institutionalization of a new governance in the higher

16 The presidency of George W. Bush, 1993-2009. 
education sector from Romania, it is important to briefly analyze the language and arguments the Report mobilized in order to narrate and illustrate the required reforms.

The Presidential Report proceeded from an open political statement:

We consider that present-day Romania is a country confronted with major risks because the education and research systems do not fulfil the minimal requirements of a European society and economy in which knowledge is the most valuable commodity and the most important source for social-economic and personal development [emphasis added] (RCP, 2007:5).

It then made a short and punctual analysis that aimed at shattering the provincial illusion that Romania had an outstanding educational system given the achievement of Romanian pupils in international competitions. The analysis (as presented in the Presidential Report) was a superficial one and made use of statistical data that had little relevance for the argument it wanted to make: for example the "non-relevance in relation with the economy and society of future" (RCP, 2007: 7) has little to do with the Lisbon indicators, this rather shows the lack of resources allocated to the educational sector and hints to the socio-structural factors that generate such outcomes bellow the European average. Nevertheless, the Report hinted to the big inequalities existing in terms of access to education between the urban and rural areas and pointed to the general exclusion of ethnic minorities, such as Roma. It also raised awareness to the lack of adequate infrastructure (building renovation, access to internet etc.), but it has done so in a language that pointed to the ageing human resources and its lack of performance. It called for professional managers and warned that "the inertia of the system is tremendous" (RCP, 2007: 9).

The analysis of the Commission heavily relied on the idea that higher education institutions had developed into uniform enterprises: in terms of their mission, education programs and human resources. The main issue emphasized by the Commission was that these universities attracted the same type of financial resources from the government regardless of their performance and, because of that, it advocated the implementation of various mechanisms of differentiation. The lack of academic excellence was considered a direct outcome of this uniformity. The proposed model was inspired by U.S. academia where through "natural evolution [sic!]" (RCP, 2007: 23) only $3 \%$ of the universities are considered "research-intensive" and only $13 \%$ offer PhD degrees. A similar case is that of Canada, where only 5 universities out of 109 are responsible for almost $50 \%$ of the PhD degrees (RCP, 2007: 23). Because universities oppose these structural changes, the policies that allocate financial resources in accordance with performance and resist the concentration of resources in the hands of elite universities, the competitiveness of the educational system had to be achieved 
"from top to bottom through a decision by the Government" (RCP, 2007: 23). This breaching of democratic processes and consultation with stakeholders is not accidental. An important reason for the lack of performance and "uniformity", according to the authors of the Presidential Report was the collegial system of governance existing in the Romanian universities. This democratic mode of governance was considered as the "first responsible for the weak performances obtained by the universities in their core activities: research, innovation, education" (RCP, 2007: 25). Instead of this, the commission advocated for a new management system that was similar to the corporate world in which managers would lead both universities and faculties: "there is a clear international tendency to replace the collegial system with a managerial that is similar to the corporatist one" (RCP, 2007: 25). Instead of democratic elections, these new managers had to be appointed with specific tasks of running the higher institutions in accordance with corporate and competitive standards.

The general language of the Presidential Report was a self-Orientalizing one that induced a culpabilization of teachers and professors for the lack of performance in the educational system. It was their corruption, mediocrity and provincialism that explained an important part of the existing failure. For example, the lack of success in attracting EU funds in education is related "solely to the incompetency" (RCP, 2007:26) of universities - and disregards the fact that these are rather systemic dysfunctionalities that are encountered in all areas (not only in education) and are characteristic to all EU peripheries. In 2010, when the President had to defend the drastic budget cuts allocated to the educational system and the $25 \%$ salary reduction of all state employees (teachers and professors included), he was echoing the same type of narrative of a lazy and unproductive professor. Referring to the weekly teaching load (and purposely excluding the time needed for preparation of classes and evaluation of students) the President unashamedly said:

I would tell the teacher that he, nevertheless, works 16 hours a week, while I have to work 16 hours a day. If he calculates the hourly payment, he might come to the conclusion that he is better paid than me by the hour. [...] It is true that I have a big salary after 30 years of work. We all had low wages in certain periods of our career. [...] On the other hand, we all have the possibility to look for a job, a half time norm. This is life in capitalism and we have to get accustomed with the idea that the first responsible for our lives are ourselves, not the state (President Traian Băsescu interviewed at Radio Romania Actualitati, Bucharest, 11.08.2010, http://www.mediafax.ro/politic/basescu-un-profesor-care-are-16-ore-pe-saptamanaeste-mai-bine-platit-ca-mine-pe-ora-6849749 [last accessed: 03.05.2015]. 
The Report advocated a more entrepreneurial educational system (RCP, 2007:27-28) and it recommended the implementation of policies that could stimulate competitiveness among universities. For example it asked for a much more flexible way of allocating money for study programs and not per student: this way each university could opt between "either covering the entire costs of a small number of students, or covering partial costs of a large number of students" (RCP, 2007: 26). It asked in various ways for privatizing parts of the higher education system in order to attract more private funding and connect the University to the business sector. But more than this, and important for the argument of this paper, it asked for the classification and hierarchization of all universities and the allocation of resources to higher education institutions based on performance. This model could ensure a "competitive university system" (RCP, 2007: 23) and instil in its employees a more pro-active and competing environment. The differentiation of higher education institutions and the concentration of resources (in the hand of few elite universities) were presented as a stringent solution for de-provincializiton and international competitiveness and the main ingredients for the development of the educational system. Given the fact that the report already established that the higher education system from Romania is characterized by "few islands of excellence immersed in a sea of mediocrity" (RCP, 2007:9) these policies aimed clearly at re-allocation of funds to those universities that could be more competitive and at the deployment of disciplinary procedures against those universities that were not. The idea behind this was to re-engineer the way education was financed in order make the higher education institutions compete more against each other for resources and enhance the quality of education through market-style mechanisms. These market-devices had to be eventually implemented in the whole Romanian educational system. Speaking of the autonomy of schools and teachers and the need for flexible curricula that has to be established by each singular unit, the Report noted:

This way, the foundations for educational competition are laid and for the positioning of each school on the market of educational services. A competitive offer will satisfy a bigger demand, will attract more pupils and so, more resources - the public money following the options the pupils make. On the contrary, a non-competitive offer will lead to a marginalization of a school leading to its abolition and to the taking over of its infrastructure by a more competitive school and relevant for the needs of recipients (RCP, 2007: 16).

The emulation of market driven competition could not be more clearly expressed, the difference being that this competition would not be between private units on a free market, but between public institutions in a competitive 
COMPETITIVENESS AND RESEARCH-ORIENTED TEACHING IN ROMANIAN UNIVERSITIES: THE NEO-LIBERAL TRANSFORMATION OF THE HIGHER EDUCATION SYSTEM

environment simulated by state. Neo-liberal reforms were this way clearly articulated for the first time in the Romanian educational system.

The Presidential Report could have stayed a simple expertise document with a high symbolic value endorsed by Presidency. Given the rift between himself and the Prime-minister who decided in the Spring of 2007 to break the existing coalition and expel from the Government members of the DemocraticLiberal Party that was led by the President before assuming office - there were reasonable expectations that the Presidential Report would have a limited impact on the existing education system. But it did not. In March 2008 the President managed to pursue all parliamentarian parties to endorse a National Pact for Education that was summarizing in 8 points almost all recommendations issued in the Presidential Report ${ }^{17}$. Some of these objectives were referring to immediate reforms that had to be implemented between 2008-2013, others were intended for a longer time period. All of the objectives referred to the above mentioned reforms of the educational system and emphasized once again international performance, competiveness, coherence of educational policies, new rules of financing, decentralization etc. But it also stated clearly that the budget for education will be increased to $6 \%$ of GDP and an additional 1\% of GDP would be allocated to research. This actually never happened, but what happened was that most of these neo-liberal reforms were gradually implemented in the Romanian educational system. The National Pact for Education was signed by representatives of all parliamentarian parties and by the President and it became the framework of most of the educational reforms that were to be implemented in coming years. Later on, the National Pact of Education was also signed by the Romanian Academy, unions, student associations and other non-governmental stakeholders - a general consensus emerged, stating that reforms and supplementary budget allocations would be needed in order to bring education to European standards ${ }^{18}$. The political Pact agreed that within 18 months after the signing of the document a comprehensive strategy of reforms in education would be elaborated.

The promised strategy was drafted by the Presidential Commission for the Analysis and Elaboration of Education and Research Policies in within a few months after the National Pact for Education was signed. On 24 of October 2008 the strategy, entitled Education and Research for the Knowledge Society - Strategy (ERKSS), was endorsed by all major trade unions and federations in education ${ }^{19}$.

\footnotetext{
17 http://www.presidency.ro/static/ordine/Pactul_National_pentru_Educatie.pdf [last accessed: 03.05.2015].

18 http://www.presidency.ro/static/ordine/COMISIA_EDUCATIE/EDUCATION_AND_RESEARCH_FOR_A_KNOWLEDGE_SOCIETY.pdf [last accessed: 03.05.2015].

${ }^{19}$ http://edu.presidency.ro/upload/Fundamentarea_demersului_legislativ.doc [last accessed: 03.05.2015].
} 
The strategy was clarifying the specific ways in which the 8 objectives outlined in the National Pact for Education were meant to be implemented. The language and the policies were the same as in the Presidential Report but it additionally presented the ways, means, objectives and calendar of the intended reforms. The neo-liberal framework still informed all the policies, but this time it hinted to the deeper mentality structures that had to be reformed as well, in order for these changes to be effective:

All the measures and actions proposed within this strategy aim not only at a new institutional and legislative commitment, but especially at a new axiological commitment, a new hierarchy of values that should make us overcome the axiological disorientation which we have experienced after 1989 [emphasis added] (ERKSS, 2008:4).

In my opinion these deep axiological structural changes that had to be embedded in the Romanian educational system for the first time after the break of the communism in order for it to be competitive on a global European scale can be summarized in two sentences that occur in the strategy:

Decentralisation is not a purpose in itself; it makes sense if it renders the system more efficient, more relevant, more equitable and qualitatively better. The state will foster competition within the educational system, by all means possible [emphasis added] (ERKSS, 2008:17).

The implementation of competitiveness and differentiation in terms of financing among individual educational institutions based on this competition was the main code-language of the new architecture of the system that runs from primary schools to post-graduate research institutions. The achievement of this strategy required the various responsible governing bodies to implement quality assurance benchmarks, institutional evaluations, assessment of didactic personnel, differentiation of wages based on performance, offer and demand tools that could instantiate market driven mechanisms to punish those institutions that were not competitive enough and enable the concentration of resources in the hands of those institutions that were capable of supplying qualitative educational services: "competition will bring about differentiation and hierarchies, will show where quality is and allow us to know whom to reward and whom to penalise" (ERKSS, 2008: 20). These reforms required the design of new evaluative meta-institutions, curricula assessments and diploma certifications, new modes of teaching and learning based on the transmission of specific competences, new ways of institutional accounting, new ways of allocating financial resources. It also required a de-politization of the institution of the school directors (principles) 
COMPETITIVENESS AND RESEARCH-ORIENTED TEACHING IN ROMANIAN UNIVERSITIES: THE NEO-LIBERAL TRANSFORMATION OF THE HIGHER EDUCATION SYSTEM

and its transformation into bureaucratic managers and technocrats that could implement these market driven mechanisms in the entire educational body. Generally speaking, the Education and Research for the Knowledge Society Strategy outlined the classic neo-liberal tools for incentivizing performance and the compelling of the system through standard governmentalization devices to produce a higher quality of educational services. I would like to dwell only on two of the objectives the strategy referred to and relate this to the higher education reforms I focus on in this paper: the second objective, of "placing at least 3 Romanian universities in the first 500 universities in the world" and the third one, on "increasing the scientific production up to 5 times and tripling the global innovation indicator, allowing us to reach the actual EU average for these indicators" (ERKSS, 2008: 4).

In order to achieve the above objectives, the strategy asked for new type of differentiation of higher educational institutions that had to take place on all existing levels: universities, faculties, departments and programs of study. The strategy asked for a way of evaluating higher institutions that could capture different types of classifications of both universities among themselves or programs of study (ex. departments that offer sociology as a degree) among themselves. This way an evaluative grid could be produced that would individualize universities as managing structures that could exert local pressure on faculties to fulfil certain quality benchmarks on one hand, and would mobilize academics within similar departments to relate their teaching and research to peers and compete against them in order to attract funding on the other. For this several measurements were proposed (ERKSS, 2008:28-32):

First, a nationwide evaluation of all higher education institutions and the creating, based on the assessment of their performance, of four hierarchical categories (in reverse order): vocational institutions, educational institutions (that would offer only undergraduate degrees), educational and research institutions (that would offer in addition master degrees) and research-intensive institutions (that would have the right to organize doctoral programs as well). Given the fact that the financing of the education was still going to be according to number of students and that this was weighted in accordance with level of education - this meant that those higher institutions that could organize $\mathrm{PhD}$ programs could attract as well more financing. This regulation was meant not only as a way of classifying universities, but also as a way of restricting those institutions that were not competitive enough to access funding.

Second, the strategy asked for a hierarchization of study programs. This meant that all curricula programs leading to a degree could be standardized and evaluated through a procedure that enabled their ranking. The reason for this was to instil in the system a selection mechanism: 
Top-level study programmes will receive priority funding by study grants. Low quality programmes from public universities will no longer receive public funding for student tuition (ERKSS, 2008: 30).

Third, an evaluation of all departments and their classification based on a five level performance scale. This measurement aimed at contractually binding rectors (managers) to distribute local funding to those departments that are competitive. If the second strategy aimed a vertical evaluation of study programs across universities, this strategy was implementing a horizontal evaluation of each single department in relation to other departments from the same university. We have to bear in mind that while the second strategy was leaving room for the professors teaching in that evaluated study program to create new programs of education in case the existing one got cancelled, the third strategy was a direct threat to those departments that would not fulfil the required standards and implicitly to their jobs:

Less competitive departments/chairs will be submitted to rigorous monitoring for 2 years, and will be liable to be dismantled if they do not significantly improve their performances (ERKSS, 2008: 30).

Forth, a new way of financing higher education institutions was established in order to make them more accountable. The strategy was advocating a differential mode of allocating financial resources and set up, consequently, three different categories of funding: basic funding (standard cost of the education of students), complementary funding (for material investments) and supplementary funding (for excellence in teaching and research). The last type of funding would play later on an important role in distributing and concentrating the financial resources in the hands of a few universities. The principle behind the differentiation among types of funding was not new, under different names these already existed in the Romanian education system (funding based on quality indicators). The novelty consisted in their formalization and the new competitive environment that was designed through the new governance policies.

Surprisingly, the Strategy encountered little opposition and was almost unchallenged in the public sphere and academia. The euphoria of the recent EU integration (2007) conveyed further legitimacy to the idea that the national education system had to be brought to the European standards through sustained efforts. The following years were also a turbulent period for the Romanian political system: the 2008 Parliamentary elections brought a new party alliance to power but, because of opposing political views (liberal-democrat versus social-democrat), this produced in this election cycle four different governments. Nevertheless, the first three governments (December 2008 - April 2012) were formed by members of the former political party to which the president belonged as well. This is why the government program for 2009-2012 was explicitly referring to 
COMPETITIVENESS AND RESEARCH-ORIENTED TEACHING IN ROMANIAN UNIVERSITIES: THE NEO-LIBERAL TRANSFORMATION OF THE HIGHER EDUCATION SYSTEM

the adoption of the Education and Research for the Knowledge Society Strategy and the implementation of the National Pact for Education ${ }^{20}$. As of December 2009, Daniel Funeriu, one of the vice-president of the Presidential Commission for the Analysis and Elaboration of Education and Research Policies, became the Minister of Education in the Emil Boc Government. The neo-liberal polices drafted in the Presidential Report and the National Strategy became government policies soon after.

We should pause for a moment and briefly contextualize the translation of these recommendations and strategies into state polices and actual reforms. In 2008, the financial crisis started to impact Eastern Europe, Romania included. Romania was hit severely by the crisis due to its dependent capitalist economy (Ban, 2014) and its reliance on foreign investments and exports. By 2008, as much as $85 \%$ of the national banking assets belonged to foreign investors and $80 \%$ of the credits were issued in the Euro currency (Ban, 2014: 227). This meant that the global financial crisis affected Romania directly and produced a decreasing exposure of the international banks and trans-national capital to Eastern Europe. Foreign investment diminished dramatically and what was the catalyst of economic growth during 2000's became soon the cause of a structural crisis (Ban, 2014: 230). In order to avoid default and restore confidence in the banking system the Romanian government agreed in March 2009 to sign a stand-by agreement with IMF and the European Commission. In exchange of external financial support the government pledged to cut public spending, reduce the fiscal deficit and implement austerity measures. This ranged from reduction of staff personal in the state sector, budgetary discipline, new fiscal policy regulations, uniformization and standardization of wages and pensions, the impossibility of promotion and new hiring in the public sector, the increase of VAT from $17 \%$ to $24 \%$. Also, as of 2010 all state employees had their wages reduced by $25 \%$, teachers and professors included. What is even more important for our analysis, the percentage of GDP allocated to education and research has significantly diminished.

In spite of all these, the government proceeded with the implementation of the above mentioned reforms and changed the National Educational Law which became effective as of 9 February 2011. The new law implemented most of the above mentioned reforms and produced a new mode of governance of the national educational system. As one regional commentator noted referring to the new classification and ranking system of higher education institutions and the allocation of funds in accordance with their performance:

20 Program de Guvernare 2009 - 2012, 2008:20, Retreived from:

http://www.cdep.ro/pdfs/guv200912/ProgramGuvernare.pdf [last accessed: 03.05.2015]. 
Romania became one of the few Eastern European countries to introduce a diversification policy based on the classification of universities and ranking of study programmes [...]. In this respect, Romania has been a very unique case, since it was the first 'attempt' in Europe to actually use a classifications and ranking exercise for such broad purposes (Sabic, 2014: 2).

In the midst of the financial crisis, budget austerity and drastic reduction of wages in the education system, the government was pioneering structural neo-liberal reforms and making efforts to implement a competitive environment and market-oriented reforms. What initially seemed a "balanced" agreement between a government oriented to market reforms on one side and labour (represented by trade unions) on the other, that implicitly stipulated that in exchange of structural reforms a bigger share of GDP $(6 \%+1 \%)$ would be allocated for education and research, was now being implemented with even scarcer resources and a stronger will to discipline state employees into becoming productive agents of national prosperity.

\section{Naturalizing the neo-liberal reform: supplementary funding and academic competitiveness}

In this section I will analyze the direct consequences of these neo-liberal reforms and the impact the new Education Law had on the distribution of funds to higher education institutions. In 2011, a massive process of evaluation of universities, based on a very complex and diversified methodology that was collecting unprecedented data about their academic and institutional performance commenced ${ }^{21}$. The purpose of this was the classification and hierarchization of universities and the allocation of funding based on their individual performance. The methodology worked with four classes of indicators: scientific research, teaching-learning, relationship with external environment and institutional capability. The weight of these indicators was different for each domain of studies, but in each single case, scientific research was the most important one and it ranged from $40 \%$ to $60 \%$. The majority of study programs had the maximum weight of $60 \%$ for the scientific research criteria from the total of quality indicators, while around $27 \%$ had the minimum weight (40\%) ${ }^{22}$. Even so, this percentage was much higher than in the previous years when scientific research had not exceeded 24\% of the total of quality indicators. Between 2011 and 2012, the direct performance of academic staff in terms of research became the main factor for the evaluation of the internal quality of a university.

\footnotetext{
21 OMECTS 4072/21.04.2011 and OMETCS 4174/2011.

22 OMECTS 5212/26.08.2011.
} 
COMPETITIVENESS AND RESEARCH-ORIENTED TEACHING IN ROMANIAN UNIVERSITIES: THE NEO-LIBERAL TRANSFORMATION OF THE HIGHER EDUCATION SYSTEM

Depending on the score it received based on these four classes of quality indicators, all national study programs were classified in five hierarchical categories (from A to E). For example, from the total of 23 political science study domains existing within all Romanian universities, only 21\% (5) received an A ranking (the highest) ${ }^{23}$. Based on the performance of its study programs and other institutional criteria, all higher institutions were classified in four categories: universities of advanced research and teaching (Class I), universities of education and scientific research (Class II), universities of education and artistic creation (Class II), and universities centred on education (Class III) ${ }^{24}$. The idea of an elite university was finally materialized, together with an array of procedures, rules and laws that enabled such differentiations.

Classification of Romanian Universities

Table 3.

\begin{tabular}{|l|c|c|c|}
\hline Percentage of Universities & Class I & Class II & Class III \\
\cline { 2 - 4 } & $13.33 \%$ & $33.33 \%$ & $53.33 \%$ \\
\hline
\end{tabular}

Source: Own computation based on the classification of universities after H.G. 789/2011.

The classification of universities had a direct effect on how student grants (budgeted study places) would be allocated, thus impacting the core funding they received based on the number of equivalent unit students. The classification of study programs directly influenced the way supplementary funding (finanțarea suplimentară) was distributed to universities. In 2012, a major change occurred in the logic of distribution of supplementary funding. While in previous years, the performance of higher education institutions was aggregated at university level, meaning that the university as a unit was reporting its outputs as a whole and that the university as unit received a share of the funding from the Ministry of Education based on qualitative indicators that was then re-distributed internally by the institution, in 2012 the algorithm ${ }^{25}$ of distribution relied on the segmentation of the total supplementary funding for each individual domain of study and then, according to the yielded ranking of each domain of study from each university (from A to E), a share of money was distributed to each institution. This meant that the supplementary funding was registered as an outcome of a much smaller unit (domain of study) which usually, but not always, corresponds to that of the department. This is why the ranking of each domain of study in relation with

\footnotetext{
23 The Methodology for the Ranking of University Programs was approved by H.G. 789/2011, and it followed the general regulations set by Art.193 of the Law on Education 1/2011.

http://uefiscdi.gov.ro/articole/2535/clasificare-universitati-si-ierarhizare-programe-de-studii.html [Last accessed: 03.05.2015].

24 OMETCS 5262/5.092011.

25 CNFIS Metodologie 2012.
} 
similar domains of study from throughout the country became a game with high stakes: the competition was not between universities anymore, the governance mechanism became finer and more precise and it identified a more exact level of intervention. Academic competition ceased to be an abstract function of big institutional structures (universities) - it was now lowered at the level of faculties (and departments) whose performances could now be measured against similar faculties and whose academic outputs determined the share of funding they would receive.

In order to distribute the supplementary funding based on above mentioned criteria, an excellence index was proposed. It was computed for each of the five possible ranks of study domains (CNFIS Metodologie, 2012: 25). The beneficiaries of the supplementary funding would generally be those universities that had study domains ranked $\mathrm{A}$ or $\mathrm{B}$, thus receiving $\mathrm{MA}$ and $\mathrm{PhD}$ budgeted places (based on a political decision).

Table 4.

Excellence index of university ranks

\begin{tabular}{|l|ccccr|}
\hline & E & D & B & C & A \\
\hline BA Level & 0 & 0 & 1 & 2 & 3 \\
\hline MA Level & 0 & 0 & 0 & 1 & 4 \\
\hline PhD Level & 0 & 0 & 0 & 1 & 5 \\
\hline
\end{tabular}

Source: CNFSIS - Raport public anual [Yearly public report] 2012.

The impact of this new governance in higher education was enormous. The following table shows how these quality indexes impacted the allocation of funds towards the various types of study programs or study domains. The negative values express how much a study program actually lost compared to the situation in which supplementary funding would have been evenly distributed for unit equivalent student and not based on quality indexes. The positive values express how much it would actually gain due to this system of distribution of funds.

Table 5.

Impact of excellence index

\begin{tabular}{|l|ccccc|}
\hline & E & D & C & B & A \\
\hline BA Level & $-27 \%$ & $-27 \%$ & $-15 \%$ & $-3 \%$ & $9 \%$ \\
\hline MA Level & $-27 \%$ & $-27 \%$ & $-27 \%$ & $-17 \%$ & $13 \%$ \\
\hline PhD Level & $-27 \%$ & $-27 \%$ & $-27 \%$ & $-20 \%$ & $8 \%$ \\
\hline
\end{tabular}

Source: CNFSIS - Raport public anual [Yearly public report]2012. 
Universities continue to be the legal beneficiaries of funding, even if performance was computed based on indicators at the level of faculties and domain of studies. This means that the universities that had mainly B, C, D and E programs received significantly less money than it received based on the quality indicators valid during last year. The impact was so strong that a lot of universities were on the verge of bankruptcy (CNFSIS - Raport, 2012) and one higher institution (Northern University from Baia Mare) had to be shut down and merged with a more successful one (Technical University from Cluj-Napoca). But some universities benefited greatly from this new mechanism. For example, Polytechnic University Bucharest received 13.2\% more money compared to the hypothetical situation that the $30 \%$ allocated through Supplementary funding ( $25 \%$ based on excellence) would have been distributed evenly among unitary equivalent students. In 2011 the same university gained an increase of only $6.7 \%$ due to the impact of quality indicators. Similarly, at the opposite end, "Lucian Blaga" University from Sibiu for example lost due to the new quality index $13.5 \%$ of total funding compared to a loss of only $5.5 \%$ the previous year due to the quality indicators. Table 6 shows the central indicators and dispersion measures of gains and losses (expressed in percentages) of all Romanian universities due to the implementation of quality indicators in 2011 and 2012: one takes into account the entire supplementary funding (30\%), the second only the segment based on excellence (25\%).

Table 6.

Universities' gains and losses following the application of differential governmental funding based on the excellence index in 2012

\begin{tabular}{|l|ccc|}
\hline & $\mathbf{2 0 1 1}$ & $\mathbf{2 0 1 2}$ (30\%) & 2012 (25\%) \\
\hline Number of universities & 49 & 49 & 49 \\
\hline Mean & -1.61 & -2.83 & -4.45 \\
\hline Std. Deviation & 4.73 & 7.76 & 8.77 \\
\hline Variance & 22.40 & 60.27 & 76.89 \\
\hline Min & $-11.5 \%$ & $-21.10 \%$ & $-22.10 \%$ \\
\hline Max & $7.70 \%$ & $13.50 \%$ & $11.10 \%$ \\
\hline
\end{tabular}

Source: Own computation based on the data provided by CNFSIS - Raport public anual [Yearly public report]2012 regarding the impact of quality indicators on each of the 49 Romanian public universities. 
The new mechanism of distributing funds to universities implemented in 2012 generated the biggest ever dispersion between higher education institutions and this was due solely to the new classification and hierarchization process that codified as the most important factor of differentiation the research done by academics. The concentration of resources in the hands of elite universities based on the meritocratic criteria that was advocated since 2007 by the Presidential Committee became now reality. No wonder that university managers started to be seriously preoccupied with the scientific productivity of its employees and to implement various surveillance mechanisms, collegial assessments and punitive measures against those that did not contribute to enhancement of internal quality of education.

The "supplementary funding" became this way the expression and equivalent of the academic research produced within each single department. Funding based on qualitative indicators existed, as we have seen since 2002, but never before did it have such a dispersive impact on the distribution of funds and never before did research have such economic relevance for universities. Supplementary funding became a fetishized concept among many academics and the general impression was, and still, is that this type of funding was something a university would receive on top of the core funding and it would represent a bonus, an extra-budgetary addition to the standard resources it usually got from the government. Something like an financial reward for excellence and outstanding teaching and research that was to be added to the basic funding. This couldn't be further from truth. As I will try to show bellow, the resources allocated to higher education institutions actually decreased and overall all universities received less money compared to the previous years. But before elaborating on this, we should pause for a moment and reflect on what it actually means that supplementary funding is allocated based on the competition between similar types of domain studies.

Let's imagine that in one hypothetical academic year all of the 23 political science departments mentioned above have an outstanding research activity. Each single member of each department publishes 10 ISI indexed scientific papers in the best available peer-reviewed journals, writes 10 exceptional books with the leading publishing houses, presents 10 working-papers at the main international conferences, delivers 10 key-note guest lectures and acts as the director of 10 important, well-funded research grants. And on top of this he/she is an outstanding teacher and an active member of the department in terms of administrative duties. In short, every single member of the 23 political science departments is an industrious unit of production. All of these in one academic year, working 40 hours/week, with the limited (and most of the time simply non-existing) resources offered by the university. Such an outstanding, 
exceptional productivity will be for sure rewarded with a generous supplementary funding, a logic of abundance should follow for each of the 23 departments and shortage of resources will become a bygone era. But of course not! Because this is not the logic of the system; the system does not award productivity, does not give bonuses for excellent research. If everyone has similar research outputs their efforts cancel each other out and the resources are being divided equally among the 23 departments. The logic of a competitive academic environment has meaning and value only if it manages to differentiate departments and mobilize academics to work more in order to be a slightly more productive than the others. The way the system has been set up in the past years is not at all about stimulating research excellence; it is about competing against each other and trying to out-perform the other academics. At least in a private company operating in a free market-economy the capitalist entrepreneur can lure workers to enhance their productivity in exchange of small share of the additional profit it generates, but within a public sector what is the political value of such an neoliberal ideology in an environment where there is a constant shortage and education is continuously sub-financed?

If one of the political science departments from the above mentioned example decides to opt out from this competitive game and leave the bonuses, supplementary resources and supplementary funding based on excellence to those departments that can miraculously wring water from flint (in no more than 8 hours a day, 40 hours / a week) it would soon find out, and many already did, that this would be the shortest way to bankruptcy. Not only Class III universities came short to the limit of default, but also many Faculties from Class I universities (institutions of advanced research and teaching) experienced serious financial troubles and registered a negative balance.

This happened because simultaneously with the neo-liberal governance of education and embedding of productivity enhancement mechanisms, the resources allocated to higher education institutions diminished. As we can see in the chart below the share of GDP allocated to higher education institutions since 2007, the year when these neo-liberal reforms have begun to shape the education system, has been dramatically reduced. This means that higher education institutions and academic spaces have been configured to function in an increasing competitive environment for lesser and lesser resources. This show that the enhancement of competitively in education was not about supplementing funds based on excellence in research but about a governmentality aimed at rationalizing costs, discipline the academic workforce and make it work in a more precarious environment. 
Figure 3. Percentage of GDP allocated to higher education institutions between 2007 and 2012 in Romania

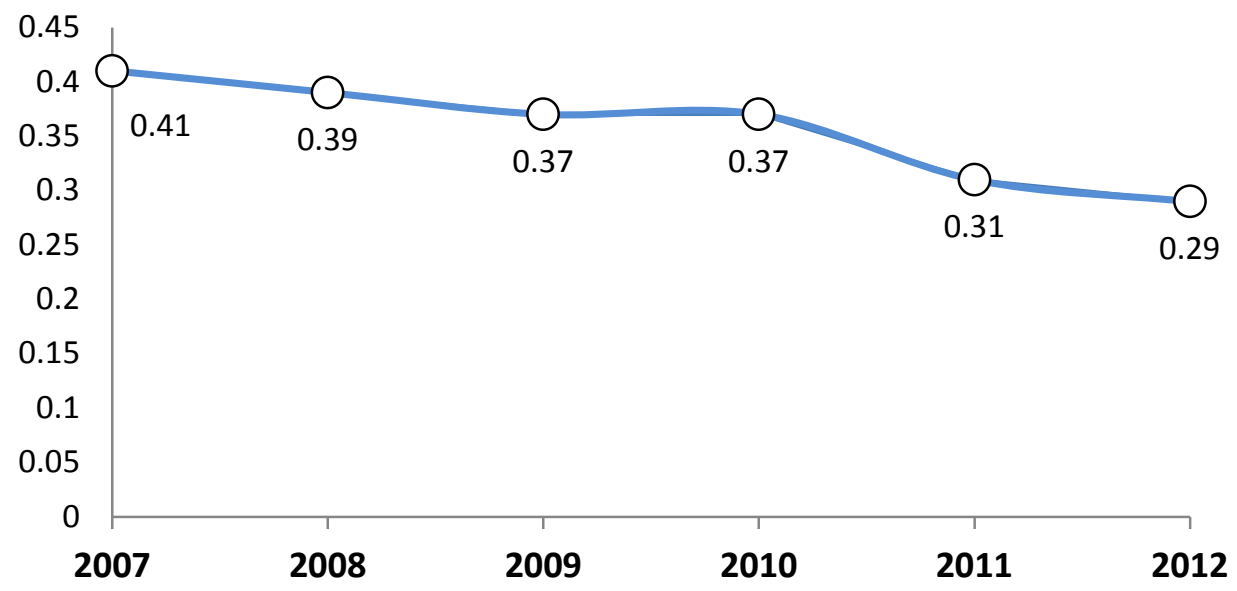

Source: CNFSIS - Raport public annual [Yearly public report] 2013.

A clearer expression of this can be obtained if we look at the evolution of the allocation per unit equivalent student (the mean sum a university receives for each unit equivalent student) or the average allocation (From 2003 there is a general increase of the both allocations until 2008 which is followed then (shortly after the beginnings of the neo-liberal reforms) by a constant drop. Nevertheless we should keep in mind that this is expressed in actual currency and is not adjusted with the growing inflation rate and diminishing purchase power. As the CNFIS, the governmental agency responsible with the financing of higher education institutions notes:

In fact, the sums of money allocated from 2003 until 2011 had approximately the same real value [...] If the core funding from the total sum has registered a modest increase in real terms in the 2003-20011 period, the allocation per unit equivalent student is in reality, when adjusted with the inflation rate, smaller in 2011 than in 2003. The difference is significant, almost 7\% from the average allocation for equivalent student at the level of 2003 (CNFSIS Raport public anual, 2012:17). 
Figure 4. The evolutions of allocation per unit equivalent student and average allocation in Romania between 2003-2012

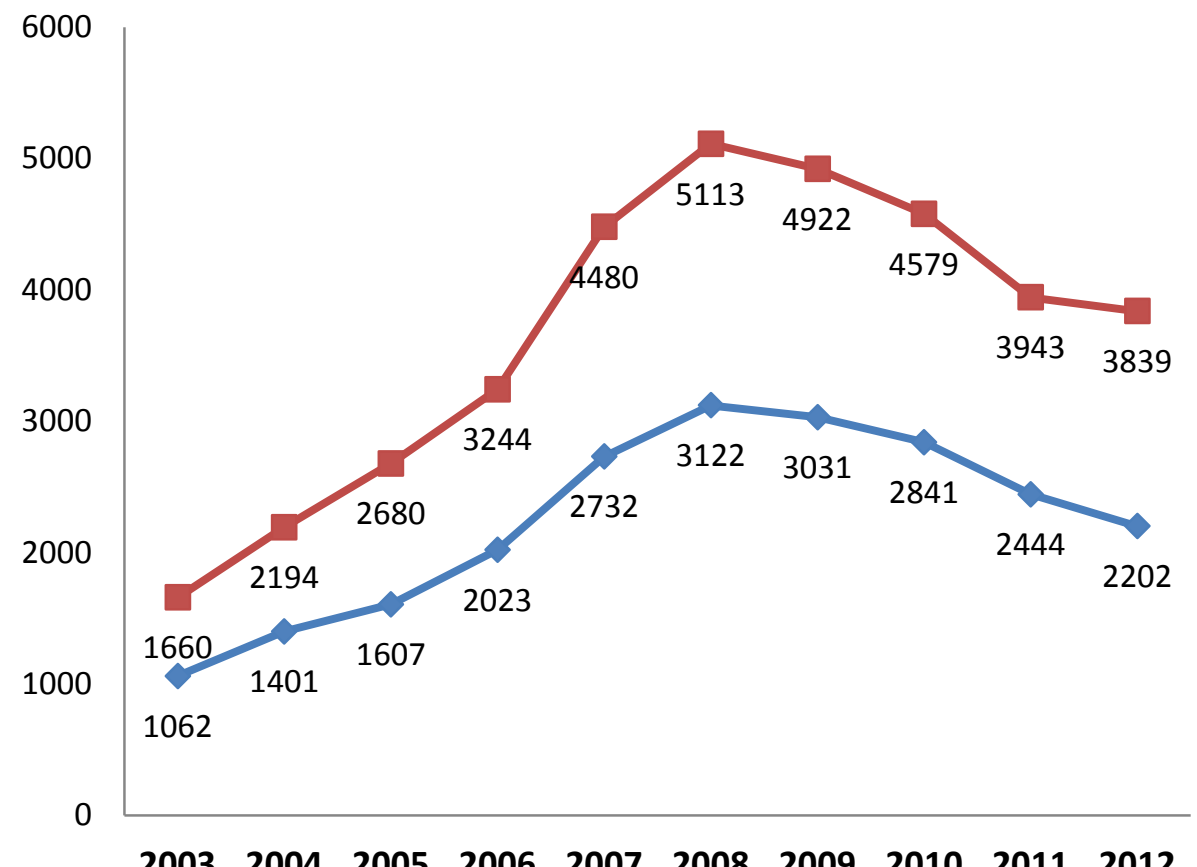

Allocation per unit equivalent student" $\quad-$ Average allocation

Source: CNFSIS - Raport public annual [Yearly public report] 2012.

The budget distributed to higher education institutions in terms of allocation per unit equivalent student was almost similar to the one in 2003 if we take into account the inflation rate. This means that the radical reforms that have begun in $2002 / 2003$ when the productivity of academics was embed in the funding based on quality indicators was not accompanied by an increase of resources invested in universities as it was promised in 2012 when the National Pact for Education was signed. The percentage from GDP was far from 6\%, in 2014 it barely reached $3.2 \%{ }^{26}$ and this enables us to point out the asymmetry between neo-liberal policies aimed at enhancing productivity of work on the one side and chronic under-financing of education on the other side.

\footnotetext{
${ }^{26}$ http://www.zf.ro/eveniment/cu-2-5-din-pib-alocate-educatiei-romania-este-la-coadaclasamentului-lumii-in-privinta-finantarii-scolii-14119678 [last accessed: 03.05.2015].
} 
By the late 2012 a regime change occurred in Romania and a new socialist-liberal coalition came to power. The 2013 methodology for distributing funds to higher education was not changed in its essence, only the quality indexes were adjusted a bit ${ }^{27}$ to enable $C$ class program of studies to access more money and consequently the variance of governmental funding among universities decreased. Even if the total supplementary funding was reduced from $30.5 \%$ to $25.5 \%$ of the total funding, this did not affect the resources allocated to the supplementary funding for excellence, which remained fixed at $25 \%$. In 2014 the socialist-liberal coalition broke and the liberals left the government: this had an immediate impact on the 2014-2015 methodology for distributing funds to higher education. In 2014, the hierarchization of universities was cancelled by a governmental decree ${ }^{28}$, but due to some internal struggles among universities the 2013 methodology was kept in place, only the quality indexes were adjusted in order to attenuate the dispersion of funding. The differentiation of universities based on categories ceased in 2015 and the system adopted the type of funding mechanism that was in place before 2012, based on 15 quality indicators. In 2015 the fraction of supplementary funding was set at $26.5 \%$ of the total funding, and $40 \%$ out of that represented quality indicators related to scientific research ${ }^{29}$. This means that $10.6 \%$ from the total funding distributed to universities was based on competition among academics in terms of research outputs. This "normalization" produced a ratio of research in the total funding higher than for the 2008-2011 period. Also the level of aggregation remained at the level of domain of studies which means that it reproduced the logic of competitiveness among academics working in the same field that was instituted in 2012. Both left and right wing political parties in Romania seem to agree that making the academic space more competitive is a straightforward way to advance reforms in higher education institutions in spite of the limited governmental resources available for education.

\section{Conclusive thoughts: notes on the precarization of academic work}

Looking back at the last 10 years of transformations of the Romanian education system, we can notice a gradual embedding and naturalization of neo-liberal disciplinary reforms in higher education institutions. The extensive academic management based on scientometrics and recurrent evaluation of

\footnotetext{
27 CNFIS - Metodologie 2013.

28 OUG $117 / 2013$.

${ }^{29}$ CNFIS - Metodologie 2015.
} 
COMPETITIVENESS AND RESEARCH-ORIENTED TEACHING IN ROMANIAN UNIVERSITIES: THE NEO-LIBERAL TRANSFORMATION OF THE HIGHER EDUCATION SYSTEM

academics that intensified in the past years is not an accident: it was part of an explicit neo-liberal agenda that started with the Presidential Report in 2007 and ended with the National Pact for Education, and so with a political agreement that materialized effectively with the new Education Law in 2011. The obsessive measuring of research outcomes, the inter-collegial evaluation of academic activity, the bureaucratization of academic spaces and the growth of administrative tasks are all direct effects of the institutionalization of neoliberal technologies of work management. Higher education institutions are shaped in accordance with the logic of markets in which academic workers are re-imagined as competitors whom the state rewards and penalizes in accordance with offer-demand tools of assessment and cost-benefit schemes of evaluation. The neo-liberal transformations managed to instigate academic institutions against each other in order to make them more productive and so it enhanced the atomization of the whole educational system with serious consequences for the educational process.

The enhancement of teaching quality through research should be an important objective of all academics that care about higher education in Romania. My critique is not aimed at the use of quality indicators and the encouraging of research-oriented teaching. On the contrary, this should be an active demand for all working in higher education and preoccupied with the impact it has on students. Research-oriented teaching represents an important dimension of making curricula more relevant and connected to state of the art literature. Rather, I contest the means through which this is achieved, namely through a neo-liberal deployment of market-oriented policies. Let us sum up briefly the logic of these transformations: the allocation per equivalent student has been significantly downsized in the past years; the money transferred to universities is not sufficient for the actual costs involved by the education process; there is a growing tendency to allocate financial resources to universities based on quality indicators; the research done by academics is becoming the most import dimension of these quality indicators; the insufficient resources are distributed according to criteria that enhance competitiveness among academics; the productivity of higher education institutions is aggregated at lower and lower institutional levels in order to enable a more exact representation of this productivity and legitimize a "meritocratic" mechanism of distributing funds; for the government this is a zero-sum game since the budget allocated to higher education is similar (or smaller) even in the case when all institutions and academics are maybe ten times as productive as during the previous year. This means that in fact the whole strategy of the neo-liberal system is to stimulate productivity through the amplification of competition among academics and not through the allocation of sufficient resources (6\% of GDP as it was promised in the National Pact for Education). 
If the resources allocated for research by universities to academics (research grants, workshop grants, travel allowances to conferences, acquisitions of relevant books) are indeed almost completely lacking, then we need to ask ourselves how exactly is research produced by academics? Where do they find the financial resources and the time needed to achieve "excellence in research" and how do they manage to combine this with their actual teaching duties? An ethnography of the academic spaces existing in those universities that in 2012-2013 were classified as universities of advanced research and teaching (Babeș-Bolyai University being one of it) could provide an important insight into how precarious "excellence in research" could become. Based on the limited observations I made in the past years as a member of various academic networks, I would like to advance the hypothesis that the majority of academics that managed to be active producers of research are those that are able to obtain (through an open competition) national and international research grants. Since Romania has one of the lowest salaries for teachers and researchers in Europe, it is not uncommon that academics are members of various research projects in order to survive financially ${ }^{30}$. Most of the times these grants are in fact second-jobs that are performed on top of the 40 hours/week teaching and research activities. In the Romanian system a research grant does not lead to a lower teaching norm and this would not even be desired by academics since this would mean a diminished monthly salary. If this is the case, then research that is reported by academics for the institutional evaluation of their performance is the outcome of the additional, private time invested in education. This surplus time becomes the source of supplementary funding received by universities from the government. This has two important effects on the academia: first, the excellence in research is produced by the university through an appropriation of academics' free time and their independent resources; second, since the system is set up to function as a competitive environment that allocates the supplementary funding to those departments that have managed to surpass similar departments from other universities, then this institutionalized accumulation of research through the appropriation of free time of academics has systemic effects on the entire academic system. If research is produced by extra-paid-work that academics perform on top of the 40 hours, then this is inscribed as the rule of competitive allocation of public resources: in order for an department to get the following year an even share from the supplementary funding, it has to be capable to produce similar research as its main competitors,

\footnotetext{
${ }^{30}$ See Teachers' and School Heads' Salaries and Allowances in Europe, 2013/14. http://www.eui.eu/ProgrammesAndFellowships/AcademicCareersObservatory/CareerComparisons/ SalaryComparisons.aspx [last accessed: 03.05.2015].
} 
COMPETITIVENESS AND RESEARCH-ORIENTED TEACHING IN ROMANIAN UNIVERSITIES: THE NEO-LIBERAL TRANSFORMATION OF THE HIGHER EDUCATION SYSTEM

and consequently to rely on external research grants and the extra-work of its faculty. Working more than 40 hours and becoming more competitive than others for the same wage is gradually imposed as the norm. This means that in the absence of strong academic work regulation, the system has the potential of becoming a spiral that consumes more and more of academics' free time in order to adjudicate a fair share of the supplementary funding, without which basic activities are not sustainable. Failing to work above the average and to be more productive than the average (even if this means a lot more than 40 hours a week) leads to implicit punitive measures "legitimated" on grounds of losing vital funding. This is why the intensification of evaluation procedures and the implementation of various surveillance mechanisms have the potential to lead to dispossession of personal resources and precarization of academics.

\section{CITED DOCUMENTS AND LEGISLATION}

Consiliul Național pentru Finanțarea Învățământului Superior [The National Council for the Financing of Higher Education] - CNFIS (2008). Analiza evoluției indicatorului de calitate IC6 privind "nivelul performanțelor în cercetarea științifică din universități" și influența acestuia în repartizarea alocațiilor bugetare destinate finanțării de bază [The analysis of the evolution of the quality indicator IC6 of the "level of performances in scientific research of the universities" and its influence on the distribution of budgetary allocations for the core funding]. Retrieved from:

http://vechi.cnfis.ro/index_d.html [last accessed: 03.05.2015].

CNFIS (2004). Metodologia de repartizare pe instituții de învătământ superior a alocațiilor bugetare aprobate prin Legea Bugetului pe anul 2004 [The methodology of distribution of budgetary allocations for higher education institutions approved by the Law on the State Budget for 2004]. Retrieved from:

http://vechi.cnfis.ro/index_d.html [last accessed: 03.05.2015].

CNFIS (2006, 2007, 2008, 2009, 2010, 2011). Metodologia de repartizare pe instituții de învățământ superior a alocațiilor bugetare pentru finanțarea de bază [The methodology of distribution of budgetary allocations for the core funding of higher education institutions]. Retrieved from: http://vechi.cnfis.ro/index_d.html [last accessed: 03.05.2015].

CNFIS (2012). Metodologia de alocare a fondurilor bugetare pentru finanțarea de bază și finanțarea suplimentară a instituțiilor de învățământ superior de stat din România pentru anul 2012 [The methodology of distribution of budgetary allocations for the core funding and the supplementary funding of public higher education institutions in Romania in 2012]. Retrieved from http://www.cnfis.ro/finantare/finantareacomplementara/ [last accessed: 03.05.2015]. 
CNFIS (2013, 2014, 2015). Metodologie de alocare a fondurilor bugetare pentru finanțarea de bază și finanțarea suplimentară bazată pe excelență, a instituțiilor de învățământ superior de stat din România [The methodology of distribution of budgetary allocations for the core funding and the supplementary funding based on excellence of public higher education institutions in Romania]. Retrieved from http://www.cnfis.ro/finantare/finantarea-complementara/[last accessed: 03.05.2015].

CNFIS (1999, 2000, 2001, 2002, 2003). Propuneri privind repartizarea pe instituții de învățământ superior a fondurilor aprobate prin Legea Bugetului, pentru finanțarea de bază [Proposals on the distribution of funds approved by the Law on the State Budget for the core financing]. Retrieved from http://vechi.cnfis.ro/index_f.html [last accessed: 03.05.2015].

CNFIS (2012a, 2013a). Raport public anual. Starea finanțării învățământului superior și măsurile de optimizare ce se impun [Annual Public Report. The situation of the financing of higher education and the necessary measures for its improvement]. Editors: Adrian Miroiu and Bogdan Murgescu. Bucharest: UEFISCDI - CNFIS. Retrieved from: http://www.cnfis.ro/rapoarte-cnfis/ [last accessed: 03.05.2015].

Comisia Prezidențială pentru analiza și elaborarea politicilor din domeniile educației și cercetării [The Presidential Commission for the Analysis and Design of Educational and Research Policies] - RCP (2007). Raportul Comisiei. România educației, România cercetării [The Report of the Presidential Commission. The Romania of Education, the Romania of Research]. Bucharest: The Romanian Presidency. Retrieved from http://edu.presidency.ro/?pag=15 [last accessed: 03.05.2015].

ERKSS (2008). Comisia Prezidențială pentru analiza și elaborarea politicilor din domeniile educației și cercetării [The Presidential Commission for the Analysis and Design of Educational and Research Policies] - Education and Research for a Knowledge Society - Strategy. Bucharest: The Romanian Presidency. http://www.presidency.ro/static/ordine/COMISIA_EDUCATIE/EDUCATION_AND _RESEARCH_FOR_A_KNOWLEDGE_SOCIETY.pdf [last accessed: 03.05.2015].

Hotărâre Senat UBB, Nr. 405/03.12.2012 - Metodologie privind evaluarea rezultatelor și performanțelor cadrelor didactice și de cercetare din cadrul Universității BabeșBolyai [Methodology regarding the evaluation of results and performances of teaching and research staff from Babes-Bolyai University], Retrieved from: http://senat.ubbcluj.ro/documente/hotarari/hotarari-2012-2013/ [Last accessed: 03.05.2015].

Hotărârile Consiliului de Administratie UBB, Nr. 2054/04.02.2015 - Dispozitie de serviciu privind incarcarea activitatii de cercetare pe platforma Managementul Cercetarii [Administrative disposition regarding the uploading of research activity on Management of research platform], Retrieved from:

http://www.ubbcluj.ro/ro/despre/info/infoUBB/[Last accessed: 03.05.2015].

Hotărârile Consiliului de Administratie UBB, Nr. 2627/ 11.02.2015 - Decizie privind incarcarea activitatii de cercetare pe platforma Managementul Cercetarii [Decision regarding the uploading of research activity on the Research Management Platform]. Retrieved from: http://www.ubbcluj.ro/ro/despre/info/infoUBB/

[Last accessed: 03.05.2015]. 
COMPETITIVENESS AND RESEARCH-ORIENTED TEACHING IN ROMANIAN UNIVERSITIES: THE NEO-LIBERAL TRANSFORMATION OF THE HIGHER EDUCATION SYSTEM

Hotărârile Consiliului de Administrație UBB, Nr. 2882 / 17.02.2014 - HCA privind publicatiile aferente componentei de cercetare din norma universitară [Decision regarding the publications related to the research component of academic norm]. Retrieved from: http://www.ubbcluj.ro/ro/despre/info/infoUBB/ [Last accessed: 03.05.2015].

Hotărârea de guvern H.G. 789/2011. Metodologia de ierarhizare a programelor de studii organizate de universitățile acreditate din sistemul național de învățământ conform art. 193 din Legea educației naționale nr. 1/2011 [The methodology for the ranking of university programs organized by accredited universities of the national educational system, acc. Art. 193 of the Law on Education No. 1/2011]. http://uefiscdi.gov.ro/articole/2535/clasificare-universitati-si-ierarhizareprograme-de-studii.html [Last accessed: 03.05.2015].

Ierarhizarea programelor de studii organizate de universitățile acreditate din sistemul național de învățământ conform art. 193 din Legea educației naționale nr. 1/2011 și prevederilor hotărârii Guvernului nr. 789/2011 privind aprobarea Metodologiei de evaluare în scopul clasificării universităților și ierarhizării programelor de studii, 2011 [The hierarchization of study programs organized by accredited universities from the national education system in accordance with art. 193 from Law of National Education nr. 1/2011 and provisions of Government decision nr. 789/2011 regarding the approval of the Methodology of evaluation for the purpose of calcification of universities and hierarchization of study programs, 2011 ], Retrieved from: http://chestionar.uefiscdi.ro/docs/programe_de_studii.pdf [Last accessed: 03.05.2015].

Law of National Education 1/2011, Retrieved from: http://keszei.chem.elte.hu/Bologna/Romania_Law_of_National_Education.pdf [Last accessed: 03.05.2015].

National Pact for Education, 2008, Retreived from: http://www.presidency.ro/static/ordine/Pactul_National_pentru_Educatie.pdf English translation: http://www.amcham.ro/UserFiles/seminarPaper/NATIONAL\%20PACT\%20FOR \%20EDUCATION_EN_06200955.pdf

OMECTS 5212 / 26.08.2011 - ORDIN privind aprobarea metodologiei de prelucrare a datelor și informațiilor colectate în vederea realizării evaluării primare a universităților și a evaluării programelor de studii universitare cu scopul clasificării universităților și ierarhizării programelor de studii [Disposition regarding the approval of data and information gathering procedure for the evaluation of universities and study programs with the purpose of classification of universities and hierarchization of study program]. Retrieved from: http://www.edu.ro/index.php/articles/15143 [Last accessed: 03.05.2015].

OMECTS nr. 4072 / 21.04.2011 - Ordin pentru aprobarea procedurii de colectare a datelor și informațiilor în vederea evaluării universităților și programelor de studii cu scopul clasificării universităților și ierarhizării programelor de studii [Disposition regarding the approval of data and information gathering procedure for the evaluation of universities and study programs with the purpose of classification of universities and hierarchization of study program], Retrieved from: http://www.edu.ro/index.php/articles/15143 [Last accessed: 03.05.2015]. 
OMETCS nr 4174 / 2011 - Ordin privind modificarea ordinului ministrului educației, cercetării, tineretului și sportului 4072/2011 pentru aprobarea procedurii de colectare a datelor și informațiilor în vederea evaluării universităților și programelor de studii cu scopul clasificării universităților și ierarhizării programelor de studii [Disposition regarding the modification of the disposition of Ministry of education, research, youth and sport 4072/2011 for the approval of data and information gathering procedure for the evaluation of universities and study programs with the purpose of classification of universities and hierarchization of study program].

OMETCS nr. 5262 / 09.2011 Ordin privind constatarea rezultatelor clasificării universităților, Disposition regarding the establishing of the classification results of universities] Retrieved from:

http://chestionar.uefiscdi.ro/docs/MonitorulOficial6septembrie\%202011.pdf [Last accessed: 03.05.2015]

OUG 117/2013 Ordonanta de urgenta privind modificarea si completarea Legii educatiei nationale nr. 1/2011 si pentru luarea unor masuri in domeniul invatamantului. [Government Emergency Ordinance regarding the alteration and supplementation of Law of National Education 1/2011 and for taking some measures in the domain of education] [last accessed: 03.05.2015].

Program de Guvernare [Government program] 2009 - 2012, 2008-20, Retreived from: http://www.cdep.ro/pdfs/guv200912/ProgramGuvernare.pdf [last accessed: 03.05.2015].

RCP (2007) Comisia Prezidențială pentru analiza și elaborarea politicilor din domeniile educației și cercetării [The Presidential Commission for the Analysis and Design of Educational and Research Policies] - Raportul Comisiei. România educației, România cercetării [Report of Presidential Commission for the Analysis and Elaboration of Education and Research Policies "Future Education and Research in Romania"]. Bucharest: The Romanian Presidency. Retrieved from http://edu.presidency.ro/?pag=15 [last accessed: 03.05.2015].

\section{REFERENCES}

Ban, C. (2014). Dependență și dezvoltare. Economia politică a capitalismului românesc [Dependency and Development. The Political Economy of Romanian Capitalism]. Cluj-Napoca: Tact.

Curaj, A., Deca, L., Egron-Polak, E. and Salmi, J. (Eds.) (2014). Higher Education Reforms in Romania: Between the Bologna Process and National Challenges. Springer Open. http://www.springer.com/978-3-319-08053-6 [last accessed: 03.05.2015].

The European Commission (2014). Teachers' and School Heads' Salaries and Allowances in Europe, 2013/14. Brussels: The European Commission.

http://eacea.ec.europa.eu/education/eurydice/documents/facts_and_figures/salaries.pdf [last accessed: 03.05.2015]. 
COMPETITIVENESS AND RESEARCH-ORIENTED TEACHING IN ROMANIAN UNIVERSITIES:

THE NEO-LIBERAL TRANSFORMATION OF THE HIGHER EDUCATION SYSTEM

Sabic, N. (2014). Governance through transparency tools. The case of Romanian higher education reforms. Paper presented at the EAIR 36th Annual Forum, Essen, 2014 August 27 - 30. http://eairaww.websites.xs4all.nl/forum/essen/PDF/1485.pdf [last accessed: 03.05.2015].

Stăvaru, A.M. (2012). Tendințe în consolidarea instituțională a asigurării calității învățământului superior românesc [Tendencies in the institutional consolidation of quality assurance in the Romanian higher education system]. Quality Assurance Review for Higher Education. 4(2): 109-121. 
